Article

\title{
Branding Baldung
}

\author{
Larry Silver (1)
}

check for updates

Citation: Silver, Larry. 2021. Branding Baldung. Arts 10: 70. https://doi.org/10.3390/arts 10040070

Academic Editor: Daniel M. Unger

Received: 14 July 2021

Accepted: 11 October 2021

Published: 14 October 2021

Publisher's Note: MDPI stays neutral with regard to jurisdictional claims in published maps and institutional affiliations.
History of Art Department, School of Arts and Sciences, University of Pennsylvania, Philadelphia, PA 19104, USA; lasilver@sas.upenn.edu

\begin{abstract}
Hans Baldung (1484/85-1545) emerged as an artist under the shadow of Germany's most famous contemporary artist, Albrecht Dürer (1471-1528), thus as a younger rival with considerable catching up to do. His time as a young artist with Dürer in Nuremberg (1503-ca. 1507) prompted Baldung to develop his own innovative imagery, even as it prepared him with the skills of later activity in drawings, woodcut prints, and, finally, paintings. Nuremberg also gave him his first contacts with prestigious patrons, local at first but also farther away, surely through Dürer's well established network to nobility in Saxony. Afterward, once he was out on his own, Baldung quickly turned his acquired skills and recognizable style into his own definitive, deeply pessimistic imagery about human limitations and mortality, especially when measured against the awesome, holy magnitude of Christ and the saints.
\end{abstract}

Keywords: Hans Baldung (Grien); Albrecht Dürer; Nuremberg; Strasbourg; woodcut; sixteenth century; artistic brand

Hans Baldung (1484/85-1545) emerged as an independent artist from under the shadow of Germany's most famous contemporary artist, Albrecht Dürer (1471-1528), so as a younger rival to a celebrated mentor, he operated with considerable catching up to do. ${ }^{1}$ Stemming from an educated and professionally prominent family in Strasbourg, ${ }^{2}$ we assume that Baldung's initial artistic training took place either in Strasbourg or across the Rhine in nearby Swabia. Knowing that his future needed to go through Dürer, Baldung decamped for that artist's Nuremberg workshop, where he apprenticed as an older artist of about twenty in the period 1503-07, and thus was able to assume greater local prominence (especially for local stained glass projects; see below) when Albrecht departed for a stay in Venice (1505-07). While in Nuremberg, he also acquired a nickname, "Grien”, since two other artists named Hans (Schäufelein and Süss von Kulmbach) already operated in the same space of Dürer's circle. This article will explore Baldung's increasing self-assertion after leaving the Dürer Nuremberg environment and will depict how he strove, on his return to Strasbourg as an independent master, to establish his own artistic identity or brand, sometimes as a direct contrast to, and variation on, Dürer's imagery of the ideal human form.

Ambition must have fueled Baldung even in his earliest output. The best evidence of his self-awareness and striving comes from a confident, frank, forward-facing drawing, a youthful Self-Portrait (Basel, Kupferstichkabinett; Koch 7; Figure A), ${ }^{3}$ which forms the inevitable curtain-raiser for every Baldung exhibition. ${ }^{4}$ This staring head, slightly turned, is fashioned on blue-green tinted paper with an ink base plus added brushwork with pink and opaque white highlights for its modelling strokes on the face and textured fur hat. Its identity as the artist himself can be verified by comparison to early painted self-portraits on some of Baldung's assertive small altarpiece commissions from 1507 (see below). Since the drawing is undated, its moment of creation has been disputed, with some observers placing the sitter at around age twenty (notably, Carl Koch); that is, at just the time that Baldung joined the circle around Dürer. Today, however, scholarly consensus places the work slightly earlier, just after the turn of the new century, when Baldung would have been 
eighteen or nineteen (thus around 1502) and before his Nuremberg stop. This technique suggests prior training in Ulm or Schwäbisch Gmünd, due to perceived similarities to the art of Bernhard Strigel. However, Dürer was already renowned for his own self-portrait drawings and paintings, so Baldung's virtuoso self-representation shows his own early desire to imitate and even surpass his older rival, possibly even before the two actually met. ${ }^{5}$ This Self-Portrait was surely planned as a carefully finished independent work, a mark of accomplishment akin to Dürer's astonishingly precocious self-portrait in silverpoint at age 13 in 1484 (Vienna, Albertina; Figure B), ${ }^{6}$ which he later signed and inscribed with information about its date. ${ }^{7}$

Another Dürer achievement, much more public because it was widely circulated, was his innovation as a designer of woodcuts, whose blocks were carved for printing by a specialist collaborator. ${ }^{8}$ Unlike Dürer, who was trained in part by his goldsmith father, Baldung rarely attempted the specialized manual skill needed to make an engraving, ${ }^{9}$ but he could still be an accomplished and innovative printmaker in his own right, because he could make drawing designs on a block for translation into the carved wooden matrix for printing.

Indeed, the earliest Baldung drawings, surely made when the young man was now studying with Dürer, already resemble woodcuts in their broad parallel lines and firm contours. A good example is his dated Martyrdom of St. Barbara (1505; Berlin, Kupferstichkabinett; Koch 6; Figure C), where the main figure is identifiable from the chalice and Eucharist on the ground before her. ${ }^{10}$ Kneeling in prayer and facing leftward, her basic form derives closely from a Dürer woodcut of the The Martyrdom of St. Catherine, ${ }^{11}$ produced about half a decade earlier (ca. 1498, B. 120; Figure D). ${ }^{12}$ While Dürer's woodcut already stretches the boundaries of the medium by including ever-finer linework and cross-hatching - an innovation inaugurated in his illustrations in the dated 1498 Apocalypse book publication-Baldung, still only twenty years old, retains the more cautiously regular vocabulary of well-spaced parallel hatchings and large open spaces on the sheet of paper. Such a design readily translates into woodcut production, as we shall see, so here we observe the young artist mastering the skills of his craft; moreover, he would retain this same kind of stark, dry, and simplified woodcut linework for his mature production of woodcut prints.

Moreover, he already shows his preference for concentration on a few large-scale figures placed close to the viewer in the foreground of a setting. These two figures occupy space in the total composition, with the executioner standing tall at the right while Barbara kneels at the left, in a firm triangular outline complemented by the single, starkly rising trunk of a tree. The facial type of the saint stands close to the rounded heads of Dürer, while the standing pose of her executioner derives from recent Dürer experiments with the human body, culminating in such masterful works as his engraving of Adam and Eve (1504, B. 1; Figure E), a work issued just as Baldung was included in the workshop. ${ }^{13}$ Moreover, the positioning of the swordsman creates spatial depth, because he is seen from behind in lost profile, not only reaching over to his victim but also turning toward her slightly in space. In later years, Baldung would veer toward much more unconventional representations of holy figures, but he always focused on the placement of his selected principals closely in front of the viewer. Compared to the dramatic action of Dürer's Catherine woodcut, Baldung offers a more balanced, contemplative mood, visible on the impassive face of the martyr herself.

From early Dürer woodcuts, such as the Madonna of the Hares (ca. 1497, B. 102; Figure F) ${ }_{1}^{14}$ Baldung's St. Barbara also borrows the coordinated articulation of its setting. A small hillock and a framing tree, both lightly shaded with parallel hatching, lie in front of a subalpine, Germanic lake with background mountains, all lightly outlined to convey their distance through a graphic form of atmospheric perspective. Thus, Dürer provided the basic model of a saint from traditional Christian devotion, now situated in a more local experience of landscape. Another early Dürer example in woodcut of this combination 
appears in his Samson and the Lion (ca. 1497/98; B. 2), though in that work Dürer was already pushing the limits of the medium with curving outlines and intricate modeling of details. $^{15}$

Turning from Baldung's drawings from his Nuremberg years to his woodcuts reveals many of the same traits, readily transferred. Dürer's printmaking success surely spurred that ambition in his apprentice. A triad of woodcuts from Baldung's apprentice years presents a frontal Virgin and Child on a Mossy Bank (Figure G), ${ }^{16}$ complemented by flanking saints in profile who turn inward to face her: Catherine and Barbara, ${ }^{17,18}$ respectively (ca. 1505/07; Figures H,I). ${ }^{19}$ They should be viewed together at once as a triptych ensemble, rather than proceeding in sequence, as with the narrative series of prints, such as the Passion, by Dürer and his predecessors. Though Baldung never repeated this formulation, unprecedented in European prints (though later regularly adopted in the ukiyo-e woodcuts of nineteenth-century Japan), together with his increasing technical proficiency at print designing, this triptych also shows his growing confidence and independence, despite his reliance on Dürer models.

The Madonna and Child print, with its grassy bank, background pond, and small building against a hill, imitates an early Dürer engraving, the Madonna with the Monkey (ca. 1498, B.42; Figure J), ${ }^{20}$ where the background building is a wire-drawing mill from near Nuremberg, which Dürer had studied in a watercolor (ca. 1496; London, British Museum, W. 115). Baldung's version enhances the full, round face of his Madonna and also (over-)emphasizes her holiness by adding both a crown and a prominent halo to her (and the Child's) understated, ordinary earthly appearance in the Dürer print. Here, Baldung has already set a more difficult assignment for his block cutter, adding much denser crosshatched lines for the deep shadows of drapery in addition to long flowing lines of her unbound hair. Baldung confidently represents the baby in torsion on his mother's lap, touching her bodice while turning to face outward toward the viewer. The apple in his hand has a double purpose: at once to show him as the New Adam, redeeming Original Sin, as well as serving as an analogue to the kingly orb of a true ruler. Both figures are larger than Dürer's in relation to their setting, and Baldung omits all the atmospheric motion of clouds by Dürer in favor of a blank sheet for his own sky.

This Madonna dominates the view, a large pyramid, possibly to make her even more dominant in relation to the other two woodcuts. Indeed, this idea of a print triptych is itself an innovation, akin to the three-part, winged painted altarpieces, used for both public and private devotions. ${ }^{21}$

St. Catherine also displays long flowing, unbound locks beneath her floral crown and cap, as she turns to the viewer's right in her seat to face the Virgin in full profile. Again, her facial type derives from Dürer. The sword of her martyrdom by her side also tilts upward, toward the focus outside the print at the central Virgin and Child. On the ground, the broken wheel of her martyrdom expressly identifies her (in contrast to the drawing of St. Barbara, whose conventional attribute of a tower does appear in her own adjoining woodcut). Again, the dense cross-hatching models deep shadow, while parallel hatches shape the edge of her chair and the curve of her shoulder. Baldung has also stepped up his mastery of the background landscape, still distinguishing between the more fully modeled tree behind the saint and the sketchier outlines of the more distant, forested hills. He also makes a new attempt at linear perspective in the diagonal receding brick wall behind Catherine, though this formulation is not an unqualified success at foreshortening.

This triad of virginal Christian martyr-saints held a prominent place in late medieval piety, in part within a larger gathering, known as the Virgin among Virgins (Virgo inter virgines) or the Virgines capitales, located in the symbolic closed garden dedicated to the Virgin Mary herself. That subject, already represented in early fifteenth-century paintings, persisted in German devotional works into the sixteenth century. ${ }^{22}$ Moreover, these two leading saints from the Virgines capitales were often invoked as paired intercessors for the pious, and so they are also featured in the foreground of a frequently represented late medieval St. Catherine event, her mystical marriage to the infant Christ on the lap 
of the Virgin. In most versions, as in these woodcuts, Catherine is on the viewer's left, Christ's favorable right side, with Barbara balancing her on the viewer's right. Both figures closely approach the throne bearing the Virgin and Child. ${ }^{23}$ In Baldung's third woodcut, St. Barbara, the saint, seated in profile, carries her chalice and Eucharist, but at her feet sits her conventional attribute of a miniature tower. In that work, Baldung has attempted more movement of cloud and light in the sky, similar to Dürer's engravings, and he retains the complex flowing line of her unbound long hair.

Other woodcuts by Baldung from his stay in Nuremberg closely follow the model of Dürer; by their very numbers, these sheets suggest that the young artist aspired to the same kind of career as a producer of prints. After all, when Dürer wrote to his Frankfurt patron Heller in 1509, he complained about all the time that he had spent instead on a large, elaborately painted altarpiece, in lieu of prints:

I put all my skill into it, as you will see and it's painted with the finest colours I was able to get. It is underpainted. overpainted, and fine-finished with good quality ultramarine five or six times over... I am sure nobody will criticise it, unless to annoy me. And I firmly believe it will please you. No one shall ever be able to persuade me again to paint a picture involving so much work... So I shall get back to my engraving-and if I'd done that all this time, I'd be $1000 \mathrm{fl}$. richer today. ${ }^{24}$

Among the woodcuts of the period 1505-07 by Baldung, most offer conventional New Testament devotional subjects: a narrative sequence of Crucifixion (Mende 2; Figure K); $; 5$ Descent from the Cross (Mende 3); Lamentation (Mende 4); and Last Judgment (Mende 5), ${ }^{26}$ plus a series of saints (martyrdoms of Lawrence and Stephen, Mende 7-8; and main scenes for Paul, Martin, Christopher, and Sebastian, Mende 8-11; Figure L). ${ }^{27}$

Baldung's St. Sebastian provides a fascinating dialogue with Dürer's own repeated investigations into the ideal male body and the contrapposto pose. ${ }^{28}$ One of Dürer's own earliest versions of that ideality was an undated engraving, St. Sebastian at the Column (ca. 1498/99, B. 56; Figure M).$^{29}$ Baldung poses the saint tied to a tree on the right side, with a sturdy, bearded bowman in a wide stance at left. This woodcut also shows the familiar Baldung use of hatchings, relatively spare for the most part but denser for the shaded areas of the legs and the tree trunk. In his more unfettered, independent maturity, Baldung would return to make a print of a far more intensely suffering Sebastian (1514; Mende 38; Figure N), ${ }^{30}$ who slumps limply against his tree, while surrounded by dense meandering clouds and hovering angelic mourners. ${ }^{31}$ By this time, Baldung had already begun to imitate Dürer's use of an inserted plaquette with his initials HB with a G in the ligature, plus the date, something that he refrained from asserting during the apprenticeship.

Often overlooked, because it remains in situ and rarely has museum exposure, stained glass design was nevertheless one of the prestige commissions for an artist, and Dürer's own activity as glass designer has recently been featured. ${ }^{32}$ What is apparent is that Dürer's absence from the workshop during his Italian journey (1505-07) allowed Baldung to fill in for him on several key projects: the early parts of a New Testament cycle of Virgin and Christ for Nuremberg's Carmelite cloister; and, especially, the prestige commission in St Lorenz in Nuremberg for the Löffelholz windows (1506; Figure O), ${ }^{33}$ still on site. The glass itself stemmed from the leading local workshop of Veit Hirsvogel the Elder. Significantly, both sets of windows were donations by leading local patrician families; Johannes Löffelholz was, similarly to Baldung's own relatives, a learned jurist and humanist, and on the lower level, he and his wife feature their family coat of arms and patron saints, John the Baptist and Catherine, respectively. For his three scenes-Annunciation, Nativity, and Adoration of the Magi-Baldung's design is clearly shown in the facial types and hatched modeling of Madonna and the bearded magus, and is particularly evident in his frontal, full-length Catherine. Dürer's own painted Adoration of the Magi (1504; Florence, Uffizi; Figure P), ${ }^{34}$ a commission for Saxon duke Frederick the Wise, had recently been completed and influenced Baldung, not only for his glass design of the same subject but also for his earliest ambitious Nuremberg painting (see below). Baldung's figures for large-scale glass, 
however (in part due to the need for clarity in the medium, but also, as we have seen, already a trademark composition trait of the artist), are reduced in number and cluster at the immediate foreground, to interact across two separate panels as massive shapes of bright colors. Their cartoons are now lost. A decade later, Baldung would design glass for the reglazing of Freiburg minster's choir area, complementing his massive high altarpiece for the same church. ${ }^{35}$

Baldung's inroads into the prestigious circles of Nuremberg patrons are also revealed in a devotional drawing, possibly for an unexecuted glass, with a mere two figures: a standing Christ as the Man of Sorrows, holding the instruments of the Passion while standing before the cross, ${ }^{36}$ plus a kneeling donor, now identified as Christoph Scheurl II (ca. 1504; Budapest; Szépmüvészeti Múzeum; Koch 5; Figure Q). ${ }^{37}$ This work already hints at Baldung's near-hysteria regarding religious suffering, manifested clearly in his woodcut of Dead Christ Carried to Heaven by Angels (ca. 1515-17; Mende 39; Figure R) ${ }^{38}$ and with the later Sebastian woodcut. ${ }^{39}$ The ink lines permit long, crumpled drapery for Christ's loincloth as well as a florid, rising banderole of speech for the donor, presumably a prayer, since he clasps a rosary. While the portrait in contemporary dress remains more generic than specific; if it is indeed Scheurl, he was a local law scholar, who would become legal advisor to the Nuremberg city council in 1512 and author in 1516 of a Latin description of the city's political structure.

Baldung did venture into more ambitious painting during his Nuremberg period with his principal early work, the signed and dated 1507 St. Sebastian Altarpiece (Nuremberg, Germanisches Nationalmuseum) (Strauss 1976) ${ }^{40}$. Its center panel (Figure S) ${ }^{41}$ includes several archers and observers at right, facing the nearly nude saint, who seems to stand casually in contrapposto pose against his trees in the near left foreground. However, in this case, left of center, behind Sebastian, and turned in the same direction, stands the artist himself, a self-portrait in a bright red cap and bright green mantle (possibly alluding to his nickname, Grien); his gaze is directed out of the picture, directly at the viewer. Behind the saint, a Germanic mountainous landscape and gray clouds amplify Baldung's earlier print and drawing backgrounds. All the figures seem to hover calmly in fixed poses, even the brightly colored archers, who load their bows in uncertain spatial positioning. This image anchors a triptych with wings devoted to isolated standing individuals: Saints Stephen (dressed in deacon's robes with the stones of his martyrdom) and Christopher (bearing the Christ Child across a river). On the reverse are two solitary female saints: Apollonia (with her pliers and tooth) and Dorothy (carrying her basket of flowers with the Christ Child).

Highly significant in the Sebastian Triptych is the aristocratic patron of this work: Archbishop Ernst von Wettin of Magdeburg, bishop of Halle (d. 1513), from whom the picture passed to Cardinal Albrecht of Brandenburg for his own Halle collegiate church. His is the obviously individualized portrait face with a thin beard who stands at the right edge of the picture, below a contemporary weapon, a halberd. He places his right hand piously upon his heart as he gazes quietly at the vision of the martyrdom scene before him. Strikingly assertive in that self-portrait, the young artist (then approximately 23 years old) dares to insert himself obviously into the very heart, slightly off-center, of his coming-out painting, made for a prominent patron and an important site ${ }^{42}$ This, too, imitates Dürer, who had already included his self-portrait—but less obtrusively—into painted religious images during this period, including his 1504 Adoration of the Magi as well as his 1506 Feast of the Rose Garlands in Venice (Prague, Národní Gallery), and his subsequent 1508 Martyrdom of the Ten Thousand (Vienna, Kunsthistorisches Museum), also destined for the Duke of Saxony. ${ }^{43}$

In that same year, the same archbishop actually ordered a second triptych from Baldung, an Adoration of the Magi (Figure T) ${ }^{44}$ with wings devoted to Saints George and St. Maurice, holding banners, and exterior female saints, Catherine (very close to the standing saint in the St Lorenz window) and Agnes (1507; Berlin, Gemäldegalerie), all before a backdrop of trees. ${ }^{45}$ In that work, the portrait-like, bearded face of the central, standing 
king in a bright brocade robe appears to be the same donor (who also resembles his brother, Elector Frederick the Wise of Saxony). As noted above, Dürer already had serious contacts with Frederick the Wise for that Adoration of the Magi painting in 1504, and for the Martyrdom of the Ten Thousand in 1508. Thus, while Baldung may not have led the loosely organized Dürer workshop, as is sometimes asserted, he did manage to benefit from the master's absence to get major commissions in both stained glass and altarpieces.

As Joseph Koerner has discussed, Baldung sometimes operated with Dürer's model as a stimulus, to which he produced a negative response. The strongest case of this dialectic emerges in a drawing of skeletal Death with an Inverted Banner (ca. 1505-07; Basel, Kupferstichkabinett, Koch15; Figure U) ${ }^{46,47}$ The contrapposto pose of this cadaver and the downward gesture of his hand replicate Dürer's final preparatory drawing for his monumental 1504 engraving, Adam and Eve (B.1), where the pose of Adam appears in reverse. ${ }^{48}$ No Dürer work during Baldung's early apprenticeship could have been more significant, yet the perfect body and stance of an ideal male figure prior to the Fall and Original Sin is now fully undermined by the younger artist and reduced to a rotting skeleton.

Only a decade later, Death will become a major, recurrent motif in Baldung's work, often contrasting with a lovely, vital female nude in painted versions of Death and the Maiden ${ }^{49,50}$ Yet here already the figure of a rotting corpse reduced to the basics of bone and muscle, along with vestiges of hair on its skull, fully undermines the beauty of Dürer's masterwork while literally copying its pose. Moreover, the inverted banner underscores the very same process of inversion, while parodying the image of military triumph denoted by a banner, as in Baldung's painted military saints of 1507, George and Maurice. ${ }^{51}$

Thus, Baldung needed Dürer as a model against which to rebel. ${ }^{52}$ His own artistic development required a form, almost oedipal in a Freudian sense, of rejecting his artistic father figure. After leaving Nuremberg, he would deepen his eccentric approach to conventional themes and his consistently negative view of humanity, already signaled with that initial drawing of Death with Inverted Banner. Baldung's negative visual outlook first arose in formal terms, concerning the human body, which for all of its fullness and potential beauty as represented by Dürer, following Italian Renaissance imagery, Baldung saw instead as debased and corrupt, standing in the shadow of Death and susceptible to temptation and outright evil. ${ }^{53}$

Soon after leaving the Dürer environment in Nuremberg and setting out independently, Baldung turned in his own right to the Fall of Humankind, Dürer's own signature engraving of 1504 and painting of 1507 (Madrid, Prado). He then produced a 1511 woodcut of Adam and Eve (Mende 19; Figure W), ${ }^{54}$ with the prominent Latin label, Lapsus Humani Generis ("Fall of the Human Race"). In that work, the sexuality of the Fall is made explicit by Adam's act of fondling the breast of Eve and by the prominence of the serpent as well as the presence of rabbits behind the figures. ${ }^{55}$ Moreover, borrowing the very new technique of color printing from Lucas Cranach and Hans Burgkmair woodcuts, Baldung used it to intensify the dark gloom of his own northern forest setting (akin to the Dürer engraving of 1504) with an olive-grey tone block, which left only a few white highlights. ${ }^{56}$

Across the remainder of his career, Baldung would produce an ongoing theme, withvariations on the Fall in all media (paintings, prints, drawings), always emphasizing a powerful erotic tinge to their nudity. Moreover, he used the female nude to enhance the potential connection between sexuality and evil through innovative, emerging imagery of witchcraft, personified by both nubile young women with companion old hags. ${ }^{57}$ Here, too, especially in his 1510 woodcut Witches' Sabbath (Mende 16; Figure X), ${ }^{58}$ Baldung used a grey tone block to emphasize the nocturnal period of those wicked, clandestine meetings. Throughout the next decade, he would continue, especially in drawings on colored paper, to explore the interactions of nude women together. ${ }^{59}$

Thus, his time with Dürer in Nuremberg prompted Baldung to develop his own innovative imagery afterward, even as it prepared him with the artistic skills for his later 
production of drawings, woodcut prints, and, finally, paintings. Like many younger artists in Germany, Baldung also adopted Dürer's signature practice of inserting a plaquette with his monogram into his works, and he consistently included it with a date in his prints, drawings, and paintings by 1510. Nuremberg also gave him his first contacts with prestigious patrons, local at first but also farther away, surely through Dürer's well established network with nobility in Saxony. ${ }^{60}$ Afterward, once he was out on his own, Baldung quickly turned his acquired skills and recognizable style into his own definitive, deeply pessimistic imagery about human limitations and mortality, especially when measured against the conventional holy magnitude of both Christ and the saints. ${ }^{61}$ In the process, he turned Dürer's beautiful bodies against themselves, establishing his singular outlook regarding Death and sin as well as the visual style that would become his distinctive brand.

Funding: This research received no external funding.

Institutional Review Board Statement: Not applicable.

Informed Consent Statement: Not applicable.

Data Availability Statement: Not applicable.

Conflicts of Interest: The author declares no conflict of interest.

\section{Notes}

1 The catalogues of Baldung include (by medium): (von der Osten 1983; Mende 1978; Koch 1941); Major retrospectives: (Lauts 1959); and, recently, (Holger 2019), with an accompanying essay volume, (Jacob-Friesen and Jehle 2019).

2 (Brady 1975). His uncle Hieronymus Baldung was physician to Emperor Maximilian. His brother Caspar was a jurist who became Rector at the University of Freiburg im Breisgau and the successor to Sebastian Brant as city secretary of Strasbourg. https:/ / commons.wikimedia.org/wiki/File:Hans_Baldung_Grien,_Self_Portrait_(c._1504).jpg (accessed on 12 October 2021). (Jacob-Friesen 2019), no. 1 (dated ca. 1501/02), with literature; see also (Söll-Tauchert 2010; Müller 1999), no. 100 (dated ca. 1502); (Falk 1978).

5 (Hess and Eser 2012, pp. 67-72), (Jörg Robert, pp. 205-7), (Shira Brisman, pp. 261-69) (Eser); (Koerner 1993), esp. 3-51, 176-86; for Baldung's self-portraits in his painted works, ibid., 423-26, 437-40, although curiously the early Baldung Self-Portrait drawing remains undiscussed.

6 https://en.wikipedia.org/wiki/Self-Portrait_at_the_Age_of_13\#/media/File:Self-portrait_at_13_by_Albrecht_D\%C3\%BCrer.j pg (accessed on 12 October 2021).

7 Inscribed, "I drew this after myself from a mirror in the year 1484 when I was still a child. Albrecht Dürer." (Robison and Schröder 2013), no. 1.

8 Peter Schmidt, "Why Woodcut? Dürer in Search of his Medium and Role," in Hess and Eser, Early Dürer, 146-59.

9 A rare Baldung engraving, his 1507 Unequal Lovers (Mende 547), shows half-length figures of a bearded, bald old man who fondles the breast of a much younger woman, while she, staring outward, deftly picks the pocket of that lustful elder from the purse that hangs at this belt. Jacob-Friesing, Baldung Grien, 108-09, no. 25. Another, undated small engraving shows a shirtless, bearded old man within a stone window frame (ca. 1508, Mende 550). For the latter, ca. 1507, Jacob-Friesen, Baldung Grien, 96-97, no. 16; called Head of an Apostle, ca. 1508 by (Marrow and Shestack 1981, p. 111), no. 17. Baldung's short, scratchy modeling, close to his woodcuts, looks labored, so it is not surprising that he abandoned the medium soon after leaving Nuremberg. http:/ / www.hellenicaworld.com/Art/Paintings/en/Part00772.html (accessed on 12 October 2021).

11 https://www.metmuseum.org/art/collection/search/383749 (accessed on 12 October 2021).

12 Schongauer to Holbein, 238-40, no. 102; Marrow and Shestack, Prints and Drawings, 68-70, no. 3. For the Dürer woodcut, (Schoch et al. 2002), no. 128.

13 https://www.metmuseum.org/art/collection/search/336222 (accessed on 12 October 2021).

14 https://en.wikipedia.org/wiki/The_Holy_Family_with_Three_Hares\#/media/File:The_Holy_Family_with_Three_Hares_-_Albrech t_D\%C3\%BCrer_c._1496.jpg (accessed on 12 October 2021).

15 Schoch et al., Holzschnitte, 106-09, no. 127. The woodblock along with that of St. Catherine survives (New York, Metropolitan Museum). For considerations of that bold experimental woodcut modeling by (Landau and Parshall 1994). Dürer also went on to paint a similar composition for his Martyrdom of St. Catherine wing panel on his Heller Altarpiece (1507-09; lost; known from copies); Jochen Sander and Johann Schulz, "'I will make something that not many men can equal.' Dürer and the Heller Altarpiece," in (Sander 2013), Figure 8.1B. 
https: / / catalogue.swanngalleries.com/Lots/auction-lot/HANS-BALDUNG-GRIEN-Madonna-and-Child-on-a-Grassy-Bank? saleno $=2537 \& \operatorname{lot} \mathrm{No}=143 \& \mathrm{refNo}=770265$ (accessed on 12 October 2021).

https: / / www.metmuseum.org/art/collection/search/416632 (accessed on 12 October 2021).

https: / www.metmuseum.org/art/collection/search/416645 (accessed on 12 October 2021).

Jacob-Friesen, Baldung Grien, 90-91, nos. 9-11; Marrow and Shestack, Prints and Drawings, 72-79, nos. 4-6.

https:/ / www.metmuseum.org/art/collection/search/391053 (accessed on 12 October 2021).

(Jacobs 2012; Humfrey and Kemp 1990). See also for small-scale devotional diptychs, often pairing a Praying Virgin with a Blessing Christ, (Hand et al. 2006).

Stanley Weed, The Virgo inter virgines: Art and Devotion to Virgin Saints in the Low Countries and Germany, 1400-1530, Ph.D. diss (University of Pennsylvania 2002; Weed 2005). For the epitome of the earlier painting tradition in Germany, (Brinkmann and Kemperdick 2002).

As Weed, "Frederick the Wise," points out, 215, Barbara and Catherine were sometimes part of a triad of female martyr saints (Drei heilige Madl) along with St. Margaret, whose conquered dragon attribute complements Barbara's tower and Catherine's broken wheel. The Mystic Marriage of St. Catherine was painted several times by Hans Memling, for example at the center of his large St. John Altarpiece (1479: Bruges, St. John Hospital) or his smaller version with a donor (New York, Metropolitan Museum). Weed, Virgo, 135-40, 157-66, argues that Memling, stemming from the Rhineland, might have brought the subject from Germany to the Netherlands and notes how often Barbara and Catherine are paired. See also Memling's small Diptych of Jen du Cellier (after 1482; Paris, Louvre) with its main scene of the Virgo inter virgines. Weed, ibid., 167-71, notes that the mystic marriage in which Catherine becomes the bride of Christ appears in late medieval French poems but became standard in pictures only in the fifteenth century. (Muir 1996, 2012).

(Ashcroft 2017); for the lost altarpiece, Sander, Dürer, 219-25.

https:/ / www.metmuseum.org/art/collection/search/416039 (accessed on 12 October 2021).

Jacob-Friesing, Baldung Grien, 92-93, nos. 12-14; Marrow and Shestack, Prints and Drawings, 80-89, nos. 7-9.

https:/ / www.metmuseum.org/art/collection/search/416664 (accessed on 12 October 2021).

Jacob-Friesen, Baldung Grien, 292-93, nos. 131-33; Marrow and Shestack, Prints and Drawings, 90-91, no. 10. More specifically, Holger Jacob-Friesen, “Exemplarisch schön, exemplarisch leidend. Der heilige Sebastian bei Dürer und Baldung," in Jacob-Friesen and Jehle, Neue Perspektiven, 92-105.

https:/ / www.metmuseum.org/art/collection/search/391068 (accessed on 12 October 2021).

https:/ / collections.artsmia.org/art/48352/st-sebastian-bound-to-a-tree-hans-baldung (accessed on 12 October 2021).

Jacob-Friesen, Baldung Grien, 294-95, nos. 134-35; Marrow and Shestack, Prints and Drawings, 198-99, no. 48; see also ibid, 158-59, no. 31, for the more moderately eccentric Sebastian (1512; Mende 29).

Jacob-Friesen, Baldung Grien, 151-71, with later designs; Hartmut Scholz, “Baldung in Nürnberg. Neue Überlegungen Teil II: Glasmalerei," in Jacob-Friesen and Jehle, Neue Perspektiven, 58-67; Scholz, “Dürer and Stained Glass," Hess and Eser, Early Dürer, 132-45; Scholz, "Monumental Stained Glass in Southern Germany in the Age of Dürer," in (Butts and Hendrix 2000, pp. 17-42, 84-127); for Baldung, ibid., 128-33, nos. 28-30. The role of Baldung in Nuremberg glass design was first explored within the larger topic of Baldung's Nuremberg stay by (Oettinger and Knappe 1963). For later Baldung glass designs, Ariane Mensger, "Künstler im Korsett. Hans Baldung als Entwerfer für Glasgemälde," in Jacob-Friesen and Jehle, Neue Perspektiven, $168-81$.

https:/ / www.nuremberg.museum/projects / show / 462-loeffelholz-fenster (accessed on 12 October 2021).

https: / / www.uffizi.it/en/artworks / durer_adoration\#\&gid=1\&pid=1 (accessed on 12 October 2021).

Jacob-Friesen, Baldung Grien, 174-77; Von der Osten, Gemälde, 99-118, no. 26, completed 1516.

https:/ / www.akg-images.co.uk/archive/Schmerzensmann-mit-kniendem-Stifter-2UMDHUJKDNT7.html (accessed on 12 October 2021).

Jacob-Friesen, Baldung Grien, 86-87, no. 6, unsigned and undated.

https: / collections.ashmolean.org/collection/browse-9148/per_page/50/offset/66150/sort_by/object\%20type/object/39776 (accessed on 12 October 2021).

Jacob-Friesen, Baldung Grien, 120-21, nos. 35-36; Marrow and Shestack, Prints and Drawings, 204-06, no. 50.

Daniel Hess, "Baldung in Nürnberg. Neue Überlieferungen. Teil I: Tafelmalerei und Zeichnung," in Jacob-Friesen and Jehle, Neue Perspektiven, 49-57; Von der Osten, Gemälde, 49-53, no. 6. Additionally, (Bonnet and Kopp-Schmidt 2010).

https:/ / commons.wikimedia.org/wiki/File:Hans_Baldung_St_Sebastian_Altarpiece.jpg (accessed on 12 October 2021).

Söll-Tauchert, Selbstbildnis, 100-07. 
(Silver 2010). On Dürer's inserted self-portrait as witness to religious visions in his paintings, André Chastel, "Zu vier Selbstbildnissen Albrecht Dürers aus den Jahren 1506 bis 1511", in (Ullmann 1972). Additionally the Ober St Veit Altarpiece (1508; Vienna, Diocesan Museum) was completed in Dürer's absence for Frederick the Wise by unnamed assistants. Its interior Passion themes are firmly attributed to Hans Schäufelein (but the work has not been seriously studied with modern means); (Metzger 2002), XX, no. XX; (Saliger 1990; Meister um Albrecht Dürer), exh. cat. (Nuremberg: Germanisches Nationalmuseum, 1961), nos. 29-30. Dürer drawing studies for the altarpiece survive in pen and brush on blue-gray paper (Basel, Frankfurt, W. 319, 321-23), so the work was clearly delegated in absentia to the workshop.

https:/ / commons.wikimedia.org/wiki/File:Hans_Baldung_Adoration_of_the_Magi.jpg\#/media/File:Hans_Baldung_Adorati on_of_the_Magi.jpg (accessed on 12 October 2021).

45 Von der Osten, Gemälde, 42-47, no.3.

46 https://www.google.com/search?q=Baldung+Death+with+Banner\&tbm=isch\&ved=2ahUKEwiC9LWC_ufwAhVXWN8KHeZC Ah4Q2-cCegQIABAA\&oq=Baldung+Death+with+Banner\&gs_lcp=CgNpbWcQA1AAWABgpYQTaABwAHgAgAEAiAEAkgE AmAEAqgELZ3dzLXdpei1pbWc\&sclient=img\&ei=bZSuYMKJBdew_QbmhYnwAQ\&bih=1155\&biw=2560\#imgrc=we2wEO4OA jmcyM (accessed on 12 October 2021).

Jacob-Friesen, Baldung Grien, 237-38, no. 104; Schongauer to Holbein, 240-42, no. 103; Marrow and Shestack, Prints and Drawings, 96-99, no 13; (Koerner 1985); more general commentary on Baldung in Koerner, Moment of Self-Portraiture, 249-362, 411-47.

The drawing, Adam and Eve, signed with monogram and dated 1504 is in New York, Pierpont Morgan Library. Charles Talbot, ed. Dürer in America, exh. cat. (Washington: Natonal Gallery, 1971, 50-52, no. XII, a work comprising two separate sheets pasted together. https: / / en.wikipedia.org/wiki/Death_and_the_Maiden_(Baldung) (accessed on 12 October 2021). Jacob-Friesen, "Vanitas-Vergänglichkeit und Wollust", Baldung Grien, 231-45, esp. nos. 108-10; Joseph Koerner, “Der Fall Baldungs", in Jacob-Friesen and Jehle, Neue Perspektiven, 18-35; (Silver 2006).

In sixteenth-century military activity, the significance of the banner-carrier in battle for rallying troops and signaling battlefield progress meant that those individuals were under special attack and personal danger and were paid at higher rates than other soldiers; (Moxey 1989, p. 71), quotes Nuremberg Meistersinger and poet Hans Sachs for his text on a series of prints by Erhard Schön about mercenary soldiers and the significance of the ensign: "I have been appointed standard-bearer,/Chosen from the noisy ranks./Whoever sees the flag flying/ Believes his side will win/Additionally, is thus encouraged to carry on the battle/Additionally, to fight with all his might./Therefore, I wave my flag/ Since it is worth my life and limbs. I will not retreat a step;/ Because of this I must be given triple pay by a powerful lord/ Who goes to war for honor and renown".

Sabine Söll-Tauchert, "Baldung versus Dürer. Wettstreit oder Gegenbild?" in Jacob-Friesen and Jehle, Neue Perspektiven, 80-91. Koerner, Moment of Self-Portraiture, 249-362, 411-47.

53 Charles Talbot, "Baldung and the Female Nude," in Marrow and Shestack, Prints and Drawings, 19-37.

54 https://www.britishmuseum.org/collection/object/P_1845--0809-922 (accessed on 12 October 2021).

55 Jacob-Friesen, Baldung Grien, 333-57, esp. 342-43, no. 167; Julia Carrasco, “Ein 'Fall' von selbstbewusster Ambivalenz," in Jacob-Friesen and Jehle, Neue Perspektiven, 106-117; (Carrasco 2019), esp. 65-98; Marrow and Shestack, Prints and Drawings, 120-23, no. 19. For this so-called chiaroscuro woodcut color printing, Landau and Parshall, Renaissance Print, 179-202. Jacob-Friesing, Baldung Grien, 315-31, nos. 152-61; Yvonne Owens, “The Hags, Viragos and Crones of Hans Baldung Grien,” Jacob-Friesing and Jehle, Neue Perspektiven, 194-203; (Brinkmann 2007); Marrow and Shestack, Prints and Drawings, 114-19, no. 18. https:/ / www.metmuseum.org/art/collection/search/336235 (accessed on 12 October 2021).

59 Besides the previous note, an important study of the lesbian sexuality in these images is Laura Weigert, "Sixteenth-Century Images of Witches and Prostitutes: Constructing Autonomy as Deviance," in (Bennett and Rosario 1995).

60 While he never became a portrait specialist, Baldung also made a number of likenesses of distinguished sitters, sometimes identifiable nobles; Jacob-Friesen, Baldung Grien, 201-29, nos. 86-99.

61 Thomas Noll, “Zum ikonographischen Stil von Hans Baldung Grien,” Jacob-Friesen and Jehle, Neue Perspektiven, 118-31; for his religious paintings, Jacob-Friesen, Baldung Grien, 129-49, 173-99; nos, 41-50, 71-83.

\section{References}

Ashcroft, Jeffrey. 2017. Albrecht Dürer. Documentary Biography. New Haven: Yale University Press, pp. $224-25$.

Bennett, Paula, and Vernon Rosario, eds. 1995. Solitary Pleasures: The Historical, Theoretical, and Literary Discourses of Autoeroticism. London: Routledge, pp. 19-47.

Bonnet, Anne-Marie, and Gabriele Kopp-Schmidt. 2010. Die Malerei der deutschen Renaissance. Munich: Schirmer Mosel, pp. $284-97$. Brady, Thomas. 1975. The Social Place of a German Renaissance Artist. Hans Baldung Grien (1484/85-1545) at Strasbourg. Central European History 8: 295-315. [CrossRef] 
Brinkmann, Bodo, and Stephan Kemperdick. 2002. Oberrheinischer Meister um 1410/20. Das Paradiesgärtlein. In Deutsche Gemälde im Städel 1300-1500. Mainz: Verlag Phillip von Zabern in Wissenschaftliche Buchgesellschaft, pp. 93-120.

Brinkmann, Bodo. 2007. Hexenlust und Sündenfall. Die seltsamen Phantasien des Hans Baldung Grien. exh. cat. Frankfurt: Städel Museum.

Butts, Barbara, and Lee Hendrix, eds. 2000. Painting on Light. Drawings and Stained Glass in the Age of Dürer and Holbein. exh. cat. Los Angeles: Getty Museum.

Carrasco, Julia. 2019. Der Sündenfall im Werk von Hans Baldung Grien. Ikonographie und Kontext. Petersberg: Imhof Verlag.

Falk, Tilman. 1978. Baldungs jugendliches Selbstbildnis: Fragen zur Herkunft seines Stiles. Zeitschrift für Schweizerische Archäologie und Kunstgeschichte 35: 217-23.

Hand, John, Catherine Metzger, and Ron Spronk. 2006. Prayers and Portraits. Unfolding the Netherlandish Diptych. exh. cat. Washington, DC: National Gallery.

Hess, Daniel, and Thomas Eser, eds. 2012. The Early Dürer. exh. cat. Nuremberg: Germanisches Nationalmuseum.

Holger, Jacob-Friesen, ed. 2019. Hans Baldung Grien. Heilig/unheilig. exh. cat. Karlsruhe: Staat-liche Kunsthalle.

Humfrey, Peter, and Martin Kemp. 1990. The Altarpiece in the Renaissance. Cambridge: Cambridge University Press.

Jacob-Friesen, Holger. 2019. Baldung Grien. München: Deutscher Kunstverlag (DKV), pp. 78-79.

Jacob-Friesen, Holger, and Oliver Jehle, eds. 2019. Hans Baldung. Neue Perspektiven auf sein Werk. Berlin: Deutscher Kunstverlag (DKV). Jacobs, Lynn. 2012. Opening Doors. The Early Netherlandish Triptych Reinterpreted. University Park: Penn State University Press.

Koch, Carl. 1941. Die Zeichnungen Hans Baldung Griens. Berlin: DEUTSCHER VEREIN.

Koerner, Joseph. 1985. The Mortification of the Image: Death as a Hermeneutic in Hans Baldung Grien. Representations 10: 52-101. [CrossRef]

Koerner, Joseph. 1993. The Moment of Self-Portraiture in German Renaissance Art. Chicago: University of Chicago Press.

Landau, David, and Peter Parshall. 1994. The Renaissance Print 1470-1550. New Haven: Yale University Press, pp. 170-74.

Lauts, Jan, ed. 1959. Hans Baldung Grien. exh. cat. Karlsruhe: Staatliche Kunsthalle.

Marrow, James, and Alan Shestack, eds. 1981. Hans Baldung Grien. Prints and Drawings. exh. cat. New Haven: Yale University Art Gallery.

Mende, Matthias. 1978. Hans Baldung Grien. Das graphische Werk. San Francisco: Alan Wofsy Fine Arts.

Metzger, Christoph. 2002. Hans Schäufelin als Maler. Berlin: Deutscher Verlag für Kunstwissensch.

Moxey, Keith. 1989. Peasants, Warriors and Wives. Popular Imagery in the Reformation. Chicago: University of Chicago Press.

Muir, Carolyn. 1996. A Study in Iconography: St. Catherine of Alexandria. In Religion, Literature, and the Arts Project. pp. 272-80. Available online: https:/ / openjournals.library.sydney.edu.au/index.php/SSR/article/view/11998 (accessed on 18 November 2020).

Muir, Carolyn. 2012. Saintly Brides and Bridegrooms: The Mystic Marriage in Northern Renaissance Art. London: Brepols, pp. 17-47.

Müller, Christian. 1999. From Schongauer to Holbein. Master Drawings from Basel and Berlin. exh. cat. Washington, DC: National Gallery.

Oettinger, Karl, and Karl-Adolf Knappe. 1963. Hans Baldung Grien und Albrecht Dürer in Nürnberg. Nuremberg: Carl, pp. 47-79.

Robison, Andrew, and Klaus Albrecht Schröder, eds. 2013. Albrecht Dürer. Master Drawings, Watercolors, and Prints from the Albertina. exh. cat. Washington, DC: National Gallery, pp. 46-47.

Saliger, Arthur. 1990. Aspekte zur künstlerischen Autorschaft des ‘Ober St Veiter Altares. In Hans Schäufelein. Nördlingen. Nördlingen: Verein Rieser Kulturtag, pp. 171-82.

Sander, Jochen, ed. 2013. Albrecht Dürer. His Art in Context. exh. cat. Frankfurt: Städel Museum, pp. $219-25$.

Schoch, Rainer, Matthias Mende, Albecht Dürer, and Anna Scherbaum. 2002. Das druckgraphische Werk II. Holzschnitte und HolzSchnittfolge. Munich: Prestel Verlag, pp. 109-11.

Silver, Larry. 2006. Pox vobiscum: Early Modern German Art and Syphilis. In Tributes in Honor of James H. Marrow. Edited by Jeffrey Hamburger and Anne Korteweg. London: Harvey Miller Publishers, pp. 465-76.

Silver, Larry. 2010. Civic Courtship: Albrecht Dürer, the Saxon Duke, and the Emperor. In The Essential Dürer. Edited by Larry Silver and Jeffrey Chipps Smith. Philadelphia: University of Pennsylvania Press, pp. 130-34.

Söll-Tauchert, Sabine. 2010. Hans Baldung Grien. Selbstbildnis und Selbstinszenierung. Cologne: Böhlau, pp. 30-56.

Strauss, Gerald. 1976. Nuremberg in the Sixteenth Century. Bloomington: Indiana University Press, pp. 58-68.

Ullmann, Ernst, ed. 1972. Albrecht Dürer: Kunst im Aufbruch. Leipzig: Karl-Marx-Universität, pp. 37-46.

von der Osten, Gert. 1983. Hans Baldung Grien. Gemälde und Dokumente. Berlin: Deutscher Verlag für Kunstwissenschaft.

Weed, Stanley. 2005. Frederick the Wise Venerating the Virgin and Saints: A Newly Reconstructed Triptych by Lucas Cranach the Elder. Konshistorisk Tidskrift 74: 209-33. [CrossRef] 